Reipolska, O. (Ed.). (2015). Formuvannia bazovykh yakostei osobystosti ditei starshoho doshkilnoho viku v DNZ [Formation of basic personality qualities of older preschool children in secondary schools]: monohrafiia. Kharkiv: Drukarnia Madryd [in Ukrainian].

Shaparenko, Kh. A. (2014). Suchasni pidkhody do trudovoho vykhovannia ditei doshkilnoho viku [Modern approaches to labor education of preschool children]. Naukovi zapysky [Natsionalnoho pedahohichnoho universytetu im. MP Drahomanova]. Seriia: Pedahohichni ta istorychni nauky [Scientific notes [National Pedagogical University. MP Dragomanova]. Series: Pedagogical and historical sciences], 116, 238-243 [in Ukrainian].

Stelmakhovych, M. H. (1997). Ukrainska narodna pedahohika [Ukrainian folk pedagogy]. Kyiv: IZMN [in Ukrainian].

\title{
STANICHENKO 0.
}

Poltava V. G. Korolenko national pedagogical University, Ukraine

\section{LABOR ACTIVITY AS A MEANS OF SENSITIVITY EDUCATION AMONG PRESCHOOL CHILDREN}

The article analyses the question of theoretical and methodological basis of labor education of preschool year children. The focus of this study is on the need to look at moral education through a retrospective of labor education. Much attention is given to the work teachers of the past (D. Locke, K. Ushinsky, A. Makarenko, V. Sukhomlinsky, etc.) who used work as a means of comprehensive development of the child. In Soviet times, thorough systematic research was conducted in this area (Z. Borysova, T. Vvedenska, V. Nechayeva, V. Pavlenchyk). Considering the issue of preschooler labor education, researchers have proved the educational significance of children's work in educational institutions, linking it with the formation of individual moral qualities. Modern Ukrainian scientists (G. Byelyenka, O. Dolynna, M. Mashovets, O. Nyzkovska) recommend to promote the active participation of children in hard work from an early age that will determine the formation of their work skills and positive attitude to work. They argue that labor education in preschool childhood contributes to the effective development of moral qualities of individual, the improvement of the educational process. The necessary moral qualities of the child's personality are formed in the relationship of labor and moral education. They are responsibility, diligence, mutual assistance, etc. The analysis of scientists' research shows that the up-todate development of this problem is marked by the lack of attention to it.

The author gives the reasons for the necessity of cultivating the sensitivity by means of labor activity within the preschool children. Extensive coverage is given to involving preschoolers in hard work that is associated with the care of animals and plants, having the aim to improve the morality of personality. The author points out that the effectiveness of the use of labor in nature as a form of work in preschool education, in order to improve children sensitivity through daily taking care of animals and plants. The author argues that sensualy-joyful knowledge of the natural environment by preschool children, their humane perception of living beings is a reliable background for the formation of sensitivity in childhood. At the same time, the study confirms that children are not isolated from suffering, grief and worries. Having the opportunity for such an experience, children understand the necessity of care process.

Key words: preschool education institution, labor education, labor activity, moral education, work in nature, sensitivity

Стаття надійшла до редакції 10.10.2020 p.

УДК 378.011.3-051:811]:37.091.12:005.336.5

https://doi.org/10.33989/2075-146x.2020.26.227649

\section{ЮЛІЯ СТРИЖАК}

ORCID 0000-0002-7289-7211

Полтавський національний педагогічний університет імені В. Г. Короленка

\section{ФОРМУВАННЯ ПРОФЕСІЙНОЇ КОМПЕТЕНТНОСТІ МАЙБУТНІХ УЧИТЕЛІВ ІНОЗЕМНОЇ МОВИ У ПРОЦЕСІ ПРОФЕСІЙНОЇ ПІДГОТОВКИ}

Комплексно схарактеризовано професійну компетентність як основу професійної підготовки майбутніх учителів іноземної мови; окреслено нові підходи до системи професійного навчання вчителя; представлено модель професійної компетентності майбутніх учителів іноземної мови.

Ключові слова: професійна компетентність, професійно-педагогічна спрямованість, професійна підготовка, іншомовна освіта

Постановка проблеми. Ефективність функціонування системи освіти та зростання соціальних вимог до навчальних закладів має потребу у висококваліфікованих спеціалістах, які здатні творчо підходити до організації навчально-виховного процесу та досягати високих якісних результатів. Підвищення якості професійної підготовки обумовлене можливістю мобільного реагування освітнього процесу на потреби суспільства та особистості. Забезпечити таку можливість покликана система управління якістю підготовки фахівця, одним з основних принципів 
побудови якої є спрямованість на формування необхідних фахівцеві компетентностей, що забезпечують його конкурентоспроможність.

Нові пріоритети і цінності розвитку українського суспільства змінили підходи до освітнього процесу на культурногуманістичних засадах. Сучасна освіта потребує формування професійної майстерності вчителів нового типу, які в умовах інноваційного освітнього середовища не тільки передають на інформаційному рівні учням знання, а й сприяють розвитку креативності їх мислення, формуванню умінь самостійної пізнавальної діяльності, самоорганізації.

Мета статті: описати професійну компетентність як основу професійної підготовки майбутніх учителів іноземної мови; визначити особливості формування професійно-педагогічної спрямованості майбутніх учителів іноземних мов.

Основні вимоги до підготовки вчителів знайшли відображення в законах України про розвиток освіти. Так, у Державній національній програмі «Освіта» (Україна XXI століття) зазначається, що «вища освіта спрямована на забезпечення фундаментальної підготовки фахівців, на формування інтелектуального потенціалу нації та всебічний розвиток особистості як найвищої цінності суспільства. Вона має стати могутнім чинником розвитку духовної культури українського народу...» (Гармаш, 2019, с. 40). У Національній доктрині розвитку освіти в Україні в XXI столітті акцентується увага на визначенні пріоритетних напрямів розвитку освіти гуманістичного характеру в нових умовах державотворення. Таким чином, державні документи України про освіту й виховання спрямовують вищі педагогічні навчальні заклади на перегляд змісту, форм, методів професійної підготовки спеціалістів. Розв'язання цих складних завдань повною мірою залежить від учителя, якості його підготовки, тому однією з актуальних проблем вищої школи є розроблення сучасної концепції професійної підготовки майбутніх вчителів.

Аналіз останніх досліджень і публікацій. У контексті нашого дослідження особливої теоретико-методологічної уваги набувають наукові розробки проблеми професійної підготовки вчителів, які всебічно висвітлено в працях А. Алексюка, В. Андрущенка, Ю. Бабанського, С. Гончаренка, Н. Гузій, М. Гриньової, О. Коберника, А. Коломієць, В. Кременя, Н. Кузьміної, Н. Мозгальової, Н. Ничкало, О. Овчарук, В. Сластьоніна, В. Шахова та ін. Безпосередньо до висвітлення сутнісних характеристик професійної підготовки вчителя звертались І. Зязюн, О. Вітковська, І. Колєснікова, Л. Коростильова, І. Кльоцина, Н. Реброва, С. Сапронова, К. Созонов, Н. Осухова, О. Пєхота та інші.

Проблемою підготовки майбутніх учителів іноземної мови займалось чимало вітчизняних і зарубіжних науковців. Зокрема, розвитку теорії і практики іншомовної освіти та підготовки майбутніх учителів іноземних мов присвячено наукові розвідки В. Андрієвської, В. Аракіна, Б. Беляєва, С. Ніколаєвої, Є. Пассова, С. Камінскі (S. Каminsky), Д. Подел (D. Podell). I. Зимня займалась вивченням психології навчання іноземних мов у школі. Сучасні технології професійної підготовки вчителя іноземної мови досліджували В.Кузовлєв, В.Карташова, С.Пассов, І.Москальова та інші.

Виклад основного матеріалу. Майбутній учитель $є$ реалізатором державної політики щодо розвитку й формування підростаючого покоління. Від підготовки вчителя значною мірою залежить професіоналізм і якість професійної діяльності майбутнього покоління. Тому на сучасному етапі розвитку національної системи педагогічної освіти значно зростають вимоги до підготовки вчителя, важливою проблемою залишається пошук ефективних шляхів, забезпечення необхідних і достатніх умов для вдосконалення процесу формування педагога як висококваліфікованого фахівця, здатного до творчої організації всіх ланок особистісно зорієнтованого педагогічного процесу, до самореалізації, до виконання нового соціального замовлення.

В усіх країнах світу реформування систем професійної підготовки здійснюється з урахуванням професійної компетентності випускників. Підготовка майбутніх спеціалістів, зорієнтованих на розвиток рівня їх готовності до професійної діяльності, є головним напрямком в удосконаленні їх кваліфікації.

Результати емпіричного дослідження (анкетування, аналіз продуктів діяльності, бесіди, спостереження) студентів ПНПУ свідчать, що психолого-педагогічні знання функціонують у мисленні студентів, стають орієнтирами для прийняття конкретних педагогічних рішень. Крім того, майбутні учителі не мають труднощів 3 організацією самостійної роботи, вміють використовувати внутрішні механізми планування, контролю та корекції професійної діяльності. Вирішальне значення в цих процесах належить професійній компетентності. Так, 80,00\% респондентів (80 осіб) зазначають, що аналізують свою готовність до педагогічної діяльності та $85 \%$ студентів спостерігають свій професійний прогрес під час навчання і університеті. I 100\% вважають, що педагог повинен володіти навичками професійної саморегуляції. Результати анкетування дозволили нам окреслити напрямки роботи, спрямованої на формування механізмів професійної саморегуляції як невід'ємної складової педагогічного процесу.

Кожний учитель повинен удосконалювати свою педагогічну майстерність, яка є вищим рівнем педагогічної діяльності, що виявляється у творчості вчителя, у постійному вдосконаленні мистецтва навчання, вихованні й розвитку людини. Педагогічна творчість розглядається як стан педагогічної діяльності, за якого відбувається створення принципово нового в змісті, організації навчально-виховного процесу, у вирішенні науково-практичних проблем. Педагогічна діяльність сучасного педагога - це прояв постійної різнобічної творчості. Вона передбачає наявність у педагога сукупності творчих здібностей, якостей, дослідницьки х умінь, серед яки х важливе місце посідають ініціативність і активність, глибока увага і спостережливість, мистецтво нестандартно мислити, багата уява та інтуїція, дослідницький підхід до аналізу навчально-виховних ситуацій, розвеязання педагогічних завдань, самостій ність думок і висновків (Зязюн, 2000, с. 214).

Головне завдання професійно-педагогічної підготовки студентів - оволодіння певним обсягом теоретичних знань 3 дисциплін педагогічного циклу, а також практичними вміннями і навичками для роботи в школі, формування особистісних якостей, потрібних майбутньому вчителю для співпраці з учнями. Провідною ланкою у змісті педагогічної освіти є теоретичний і практичний компоненти у підготовці майбутнього вчителя. Принципом освіти вчителів повинна бути багатогранність, широкий обсяг змісту навчання, пізнавання і творення цінностей, володіння необхідними здібностями. Навчання і професійне вдосконалення повинні творити основу професійного розвитку вчителя, а також сприяти оптимальному розвитку молоді та спрямуванню її розуміння проблем майбутнього. 
Найважливішим завданням професійної підготовки студентів у вищому навчаль ному закладі $є$ формування достатнього рівня професійної компетенції майбутнього вчителя.

Професійна компетенція - це сукупність теоретичних знань із педагогіки, психології, методики викладання предмета та вмінь їх практичного використання в роботі в загальноосвітньому навчальному закладі (Калюжна, 2013, с. 33).

Необхідність модернізації вищої педагогічної освіти дозволяє виділити такі базові компетентності випускника педагогічного ЗВО:

1) прийняття активної життєвої і професійної позиції;

2) орієнтація на соціальне і професійне самовизначення і самореалізацію, здатність до самоорганізації;

3) освоєння основних професійних навиків, практичних умінь у професійній сфері;

4) формування й володіння професійними цінностями і якостями, що відповідають загальнолюдським нормам;

5) досягнення сучасного загальнокультурного рівня і сформованість професійної культури.

У підготовці педагога важливими є такі характеристики: професіональна мотивація, фундаментальність, методологічна обгрунтованість, професійна направленість підготовки студентів, багатофункціональність, комплексність у змісті, організації, методиці та контролі, емоційна насиченість, активізація самостійної пошукової навчальної та науково-дослідної роботи студентів.

Наше суспільство зацікавлене у фахівцях, здатних самостійно діяти, приймати рішення, відповідати за їх реалізацію, адаптуватися до мінливих умов сьогодення. Педагогіка завжди прагнула відповідати вимогам прогресивного розвитку людини і суспільства. Для поліпшення підготовки майбутніх учителів у сучасній концепції педагогічної освіти розроблено нові підходи до системи професійного навчання вчителя. Основними чинниками нових підходів до підготовки вчителя є:

- соціально-економічні (зміни в суспільній свідомості та поява нових цінностей в освіті, інтереси особистості мають більше значення, ніж навчальні програми та плани, створюються умови для постійного звеличення людини, гармонізації ії відносин із державою, природою, суспільством тощо);

- практичні (поява нових типів навчальних закладів, окрім загальноосвітньої школи, для ни х потрібен учитель 3 цілісним уявленням про професійну діяльність, який повинен оволодіти у процесі психолого-педагогічної підготовки спеціальними вміннями та навичками взаємодії та спілкування; для того щоб підготовка вчителя відповідала сучасним вимогам, потрібно активізувати розробку методологічної та теоретичної основи педагогічної освіти);

- теоретичні (зумовлені соціально-економічними та практичними змінами у розвитку народної освіти; педагогічна освіта розвивається шляхом формування у педагогів цілісного уявлення про свою професійну діяльніс ть, через це більшість педагогічних закладів України у навчальні плани включає інтегровані курси психолого-педагогічних дисциплін і на цій основі цілеспрямовано організовує формування професійно важливих якостей майбутнього вчителя, його професійної свідомості, поведінки та розвитку індивідуальності) (Гармаш, 2019, с. 41).

Викладачу необхідно навчитися будувати викладання предмета разом зі студентом, адаптуючи його до того, що $\epsilon$ у ЗВО, і готувати до майбутньої професійної діяльності. Те хнології підготовки вчителя повинні забезпечувати субеектну позицію того, кого навчають, у ході його пізнавальної діяльності, орієнтувати його на постійний саморозвиток. Цьому сприяє індивідуалізація педагогічної підготовки, в результаті якої майбутній учитель працює за індивідуальною освітньюю програмою, складає професійний автопортрет, учиться формулювати і забезпечувати особисту педагогічну концепцію, стратегію і тактику професійної життєдіяльності.

Важливо використовувати в педагогічних дисциплінах проектні технології, вчити майбутнього вчителя створювати проекти шкіл сьогоднішнього і завтрашнього дня, проектувати і будувати професійні стосунки. постає проблема використання можливостей формувати професійно-педагогічну спрямованість у майбутніх учителів під час професійної підготовки. Основним завданням викладання іноземних мов сьогодні в Україні є навчання мови як реальному і повноцінному засобу спілкування. Успішність спілкування, у свою чергу, залежить від бажання контактувати, уміння реалізовувати мовленнєвий намір, ступеня володіння одиницями мови й уміння вживати їх у конкретних ситуаціях спілкування. Ці компоненти напряму залежать від професійно-педагогічної спрямованості майбутніх учителів іноземних мов, адже, на нашу думку, сприяють більш мотивованому засвоєнню навчальних матеріалів у процесі фахової підготовки.

Досягти таких результатів можливо за умови врахування особливостей професійно-педагогічної спрямованості майбутніх учителів іноземних мов, серед яких, на основі власного досвіду та проведеного аналізу наукових джерел, ми виділили такі:

- усвідомлення необхідності постійного особистісного та професійного саморозвитку, потребу в обраній професії.

- у уміння реалізовувати мовленнєвий намір, що базується на особливому підході до вивчення іноземної мови (заучування), здатність безпомилково виконувати мовленнєві операції;

- систематичність праці вчителя іноземної мови, що передбачає постійний контроль усних комунікативних навичок, накопичення культурних, лінгвістичних та літературних знань мови, яку він викладає;

- постійне спілкування з учнями (на протязі всього процесу вивчення іноземної мови у шкільному курсі), уміння спостерігати, критично оцінювати їх здобутки;

- розширення кругозору учнів, їх загальної ерудиції засобами мови, що вивчається, шляхом проектування вивчення іноземної мови на подальші життєві перспективи.

Проведений аналіз наукової літератури та досліджень, присвячених питанням фахової підготовки майбутніх учителів іноземних мов, дозволив визначити особливості та сутність їхньої професійно-педагогічної спрямованості, під якою ми розуміємо інтегральну професійну якість особистості, що передбачає сталий інтерес до професії вчителя 
іноземних мов, потребу в систематичній та безперервній роботі над собою та над розвитком власних комунікативних навичок, бажання постійно контактувати з учнями та навчати їх досвіду іншомовного спілкування.

За визначенням В.Адольфа та І.Степанової, професійна компетентність - це якість особистості, яка завершила освіту певного професійного рівня, і ця якість виражена в готовності до успішної, продуктивної, ефективної професійної діяльності з урахуванням її соціальної значущості і соціальних ризиків, які можуть бути пов'язані з нею (Бочарникова, 2012, с. 23). Повною мірою професійна компетентність може виявлятись лише у вчителя, який практикує. Однак вже в період навчання у вищому навчальному закладі формуються ії основні засади. Студенти отримують психологічну підготовку й завдяки цьому можуть усвідомлювати професійну компетентність як психологічну категорію і виявляти ії професійний аспект.

Тож модель професійної компетентності може бути представлена як єдність теоретичної та практичної підготовки майбутнього педагога до професійної діяльності. Перспективним у процесі реалізації компетентнісного підходу може стати знову ж таки метод моделювання. Як стверджують В.Шаповалов та В. Горова, технологія формування компетентності спеціаліста може будуватись як процес перетворення навчальної діяльності студента в професійну діяльність спеціаліста (Калюжна, 2013, с. 35), де педагогічне моделювання відіграє одну з найважливіших ролей.

У якості нової стратегічної цілі іншомовної освіти можна виділити не просто практичне оволодіння іноземною мовою як комунікативним засобом, але й формування у свідомості студента так званої «картини світу», притаманної носієві цієї мови як представнику певного соціуму.

Згідно з сучасними вимогами до іншомовної освіти, підготовка вчителів іноземної мови повинна мати яскраво виражений культурологічний характер і бути націлена «на вироблення адекватної поведінки у спілкуванні з носіями культури країни, мова якої вивчається, на основі знань не тільки мови, але й ментальності, стилю повсякденного життя, традицій та звичаїв народу» (Бочарникова, 2012, с. 24). Навчальний матеріал повинен бути автентичним за змістом і мовним наповненням, оскільки тільки оригінальні тексти, насичені соціокультурною інформацією, можуть допомогти майбутнім учителям виробити здібності розуміти і сприймати чужу культуру.

Ефективність роботи зросте, якщо ширше застосовувати форми занять, що дають змогу максимально враховувати нахили і творчі здібності здобувачів освіти, їх пізнавальні інтереси й життєві пріоритети; формувати активну життєву позицію; спонукати студентів аналізувати реальні життєві моральні, суспільно-політичні ситуації в усій їх складності й суперечностях; моделювати навчальні ситуації, які сприяють розвиткові компетентностей, розв'язувати їх i приймати оптимальні рішення; систематично практикувати різні форми презентації й застосування знань, індивідуальні та групові проекти, лекційно-семінарські форми занять, дискусії, диспути, заліки; задіювати дослідницькі функції в освітньому процесі, формувати відповідні навички; залучати студентів до експериментування, виконання індивідуальних творчих завдань; використовувати переваги IКТ; розвивати різнобічні інтереси; забезпечувати високий позитивний емоційний потенціал занять іноземної мови.

Висновки. Необхідно удосконалити професійну підготовку майбутніх учителів і посилити роль учителя в суспільстві. Одним із важливих чинників цього $є$ визначення вимог до майбутніх учителів, до їх професійної підготовки, яка повинна бути орієнтована на багатогранну майбутню професійну діяльність. Професійна підготовка майбутніх учителів іноземної мови повинна мати на меті не тільки засвоєння студентами сучасних знань із загальнопрофесійних і фахових дисциплін, виховання високоосвіченої, культурної, гармонійно розвиненої особистості, а й пропагувати ідеї здорове язберігаючого та ціложиттєвого навчання, освіти в інтересах сталого розвитку, компетентнісного підходу, демократії, створення єдиної зони європейської освіти, толерантності.

Перспективи наших подальших досліджень полягають у виявленні психолого-педагогічних умов, розробленні методичного забезпечення для формування професійної компетентності у педагогічній діяльності.

\section{Список використаних джерел}

Бочарникова, Т. Ф. (2012). Особливості професійно-педагогічної спрямованості майбутніх учителів іноземних мов. В кн. Проблеми інженерно-педагогічної освіти: зб. наук. пр. (№ 36, с. 21-25.). Харків.

Гармаш, О. М. (2019). Професійна підготовка майбутніх учителів іноземних мов як педагогічна проблема. Науковий часопис Начіонального педагогічного університету імені М. П. Драгоманова, 66, 39-42.

Зязюн, І. А. (2000). Інтелектуально-творчий розвиток особистості в умовах неперервної освіти. Неперервна професійна освіта: проблеми, пошуки, перспективи. Київ: Віпол.

Калюжна, Т. Г. (2013). Сучасні вимоги до професійної підготовки майбутнього вчителя. Наукові записки Ніжинського держсавного університету ім. Миколи Гоголя. Серія: Психолого-педагогічні науки, 4, 32-37.

Ніколаєва, С. Ю. (1996). Ступенева система освіти в Україні та система навчання іноземних мов. Київ: Ленвіт.

\section{References}

Bocharnykova, T. F. (2012). Osoblyvosti profesiino-pedahohichnoi spriamovanosti maibutnikh uchyteliv inozemnykh mov [Features of professional and pedagogical orientation of future teachers of foreign languages]. In Problemy inzhenerno-pedahohichnoi osvity [Problems of engineering and pedagogical education]: zb. nauk. pr. (No 36, pp. 21-25.). Kharkiv [in Ukrainian].

Harmash, O. M. (2019). Profesiina pidhotovka maibutnikh uchyteliv inozemnykh mov yak pedahohichna problema [Professional training of future foreign language teachers as a pedagogical problem]. Naukovyi chasopys Natsionalnoho pedahohichnoho universytetu imeni M. P. Drahomanova [Scientific journal of the National Pedagogical University named after MP Drahomanov], 66, 39-42 [in Ukrainian]. 
Kaliuzhna, T. H. (2013). Suchasni vymohy do profesiinoi pidhotovky maibutnoho vchytelia [Modern requirements for professional training of future teachers]. Naukovi zapysky Nizhynskoho derzhavnoho universytetu im. Mykoly Hoholia. Seriia: Psykholoho-pedahohichni nauky [Scientific notes of Nizhyn State University. Nikolai Gogol. Seriy: Psychological and pedagogical sciences], 4, 32-37 [in Ukrainian].

Nikolaieva, S. Yu. (1996). Stupeneva systema osvity v Ukraini ta systema navchannia inozemnykh mov [Degree system of education in Ukraine and the system of teaching foreign languages]. Kyiv: Lenvit [in Ukrainian].

Ziaziun, I. A. (2000). Intelektualno-tvorchyi rozvytok osobystosti v umovakh neperervnoi osvity. Neperervna profesiina osvita: problemy, poshuky, perspektyvy [Intellectual and creative development of personality in the conditions of continuous education. Continuing professional education: problems, searches, prospects]. Kyiv: Vipol [in Ukrainian].

\title{
STRYZHAK Y.
}

Poltava V. G. Korolenko national pedagogical University, Ukraine

\section{FORMATION OF PROFESSIONAL COMPETENCE OF FUTURE FOREIGN LANGUAGE TEACHERS IN THE PROCESS OF PROFESSIONAL TRAINING}

The study is comprehensively characterized professional competence as a basis for professional training of future foreign language teachers; new approaches to the system of professional teacher training are outlined; the model of professional competence of future foreign language teachers is presented.

The future teacher is the implementer of the state policy on the development and formation of the younger generation. The professionalism and quality of professional activity of the future generation largely depends on teacher training.

The analysis of scientific literature and research on the issues of professional training of future teachers of foreign languages allowed determining the features and essence of their professional and pedagogical orientation. Under the professional and pedagogical orientation of the future foreign language teacher we understand the integral professional quality of the individual, which implies a constant interest in the profession of foreign language teacher, the need for systematic and continuous work on themselves and their own communication skills, desire to constantly communicate with students and teach them foreign language communication.

It has been concluded that it is necessary to improve the professional training of future teachers and strengthen the role of teachers in society. One of the important factors in this is the definition of requirements for future teachers, for their professional training, which should be focused on multifaceted future professional activities.

Key words: professional competence, professional and pedagogical orientation, vocational training, foreign language education

Стаття надійшла до редакції 23.09.2020 р.

УДК:373.3/.5.048:331.548](091)(410)"192"

https://doi.org/10.33989/2075-146x.2020.26.227654

\section{МАРІЯ ТИМЕНКО}

ORCID: 0000-0002-7639-5630

Інститут педагогіки Національної академії педагогічних наук України, м. Київ

\section{НАВИЧКИ ХХІ СТОЛІТТЯ У ШКІЛЬНІЙ ОСВІТІ У ВЕЛИКІЙ БРИТАНІї}

\begin{abstract}
Автор розглядає та характеризує основні сучасні тенденції розвитку шкільної освіти у Великій Британії. Описано необхідні навички XXI століття учнів середніх навчальних закладів Великої Британії (спільне вирішення проблем, відповідальність, критичне мислення, творчість, емоційний інтелект, співпраця, прийняття рішень, навички IT, саморегуляція, комунікація, гнучкість і пристосовуваність, повага, інформаційна та економічна грамотність та ін) і умови їхнього формування. Схарактеризовано так звані soft skills (гнучкі навички) i hard skills (жорсткі навички). Окреслено роль учителя XXI століття, що на сьогодні не може обмежуватись передачею знань, але орієнтуватися, обговорювати і звичайно, оцінювати прогрес виконання студентами завдань, щоб вони знали, коли більше необхідна підтримка, так як сьогодні інноваційні школи проектують класи для прагнення до знань, а не його транспортування.
\end{abstract}

Ключові слова: навички, икільна освіта, Велика Британія, тендениії

Постанова проблеми. Освіта на початку XXI століття характеризується активізацією тенденцій, спрямованих на інноваційний розвиток, що підвищить ефективність навчального процесу. Початок ХХІ століття характеризується появою досліджень, що характеризують особливості розвитку інноваційних процесів у конкретних предметних областях. 